\title{
Identification of Factors Causing Delays in Construction Projects in Algeria
}

\author{
Roumeissa Salhi \\ PhD Cand. Dept. of Civil Engineering, University 20 Août 1955 Skikda, Algeria \\ Karima Messaoudi \\ Prof., Dept. of Civil Engineering, University 20 Août 1955 Skikda, Algeria \\ Souad Sassi Boudemagh \\ Prof., Laboratory LAVMF, University Salah Boubnider Constantine3, Algeria
}

\begin{abstract}
Time is an indicator of project performance, and along with cost and quality factors, it is the project roadmap, as it determines its success. In Algeria, among the problems often encountered in the construction of projects are timeouts. A questionnaire survey was conducted with experts in the field of construction, in order to know the factors causing delays in projects. The results show that the managerial factors (relating to planning, organization and management) are the most important in Algeria. Therefore, the use of Project Management is essential, given the need to promote this area in terms of processes and tools used, to allow the various project stakeholders to optimize the planning of activities and resources, to complete the project. project in a timely manner and reach the stage of project success. Recommendations were proposed and managerial solutions were suggested using the guide of PMBOK version 5.
\end{abstract}

Keywords: Construction project, deadlines, delay, project sucess, delay factors, project management, Algeria.

\section{Introduction}

Succeeding a project has never been a simple act because it is conditioned by specific constraints of cost, time and quality.

Among the problems often encountered in project construction are time-outs; a lot of research has been done to identify the factors of delay: Assaf and al-Hejji (in 2006) in Saudi Arabia, made a field survey on the delay in construction projects. 73 causes of delay were identified and categorized into 9 groups and classified according to: their severity, frequency and importance. The most common identified cause is "change of the project order by the project owner during construction". Time-out average was also discussed and it is found between $10 \%$ and $30 \%$ of the initial duration; they concluded that $70 \%$ of the projects experienced time overruns. Similarly, Long, Young and Jun (in 2008) conducted a survey in Vietnam to find out the causes of delays and cost overruns. 21 causes of delay were inferred and evaluated in relation to frequency, severity and importance; the factor analysis technique was also applied to sort out the main causes of time overruns and costs. A comparison between Asia and Africa ranked 5 important factors: poor site management and supervision; poor project management assistance; financial difficulties of owner; financial difficulty of contractor; design changes. Also, Mohan, Kumaraswamy, Daniel and Chan (in 2010), studied the causes of delays in construction projects in Hong Kong. They analyzed 83 delay factors, then categorized them into 8 groups of factors, and ranked them according to their importance from a common point of view among the different project participants as follows: poor site management and supervision ; unforeseen ground conditions; delays in design information ; lack of communication between consultant and contractor ; 
inadequate contract experience ; low speed of decision making. While, M. Gündüz, Y. Nielsen and M.Özdemir (in 2013), identified 83 causes of delay, then they grouped and visualized them using "Ishikawa diagram" to show the relationships between the different causes and groups and their consequences. Interviews and questionnaires were established to assess the perception of these causes in Turkish construction. The analysis of the data is done using the index of relative importance, to quantify and classify these causes according to their degree of importance, in order to minimize or avoid delays in future projects. However, O.Bayana and J.Song (in 2016) conducted a questionnaire survey of 140 experts to identify the most frequent, serious and significant causes of delay in projects in Burkina Faso. The 5 main factors are: financial capability of the contractor; financial difficulties of the owner; equipment availability of the contractor; slow payment for completed work; poor subcontractor performance by the contractor. A comparison of the causes of delay in 11 other countries shows that the financial capability of the contractor was the factor most met in Burkina Faso, but also in many other Asian and African countries.

The effects of delay have also been discussed in several studies, and suggestions have been made to alleviate these effects:

In their study of 61 construction projects in Nigeria, Aibinu and Jagboro (in 2002) identified the effects of delays on project cost and completion date. The 6 main effects are: timeoverrun, cost overrun, dispute, arbitration, total abandonment and litigation. They also found that to reduce the negative effect of the delays it is necessary: the acceleration of subsequent site activities to reduce or if possible eliminate time overrun; and the inclusion of contingency allowance in precontract estimate to buffer cost overrun. Thus, Yakubu and Ming (in 2010) conducted a survey on 250 construction project organizations in the UK, followed by interviews with experienced practitioners from 15 of these organizations, and identified factors inhibiting time control. The five most important factors are: design change; risks and uncertainties; inaccurate evaluation of project time; complexities and non-performance of subcontractors. Subsequently, 90 mitigation measures for these factors were developed and classified as: preventive; predictive; corrective and organizational measures. Moreover, A. H. Alavifar, S.Q. Resalat, S. Motamedi (in 2014), in their study on time delay risks of construction projects in Iran have shown that the delay has a negative effect on the different aspects of project, among these effects: the legal problems between employer, consultant and contractor, decreased productivity and revenue, unfinished large project. Thus, they identified 26 delay factors and then ranked them according to their frequency of occurrence, degree of severity and importance based on the views of the 3 project parts. Then, they categorized these factors into three level of problems: strategic problems, systematic problems and managerial problems. In the end, they proposed solutions for managerial problems.

In Algeria, even if the programming of infrastructures and buildings is important and despite the availability of means; projects continue to be delayed. An important question emerges: what can be the real causes behind this problem and how can it be overcome?

\section{Research methodology}

A questionnaire survey was conducted among 175 specialists in the construction field, 118 responses were returned. The questionnaire consists of 3 parts; the first concerning the general information of the respondents; the second part contains questions about the projects, the third part is designed for the evaluation of 84 delay factors according to their frequencies, severities and importances, using statistical indices (frequency index, severity index and the index of importance).

Frequency index: $($ F.I. $)=\frac{\sum a n}{N}$

Where: $\mathbf{a}$ : is a constant that expresses the weight given to each factor, varies from 1 to $5(1=$ Never, $2=$ rarely, $3=$ sometimes, 4 = frequently, 5 = always), $\mathbf{n}$ : the response frequency, $\mathbf{N}$ : the total number of respondents or answers

Severity index $:($ S.I. $)=\frac{\sum a n}{N}$.

Where: a: is a constant that expresses the weight given to each factor, varies from 1 to 5 ( $1=$ low, $2=$ medium, $3=$ serious, $4=$ very serious, 5 = extremely serious), $\mathbf{n}$ : the response frequency, $\mathbf{N}$ : the total number of respondents or answers

Importance index: (IMP.I.)= IF*SI 


\section{Discussion and results}

The results show that $62 \%$ of the projects in Algeria experienced timeouts. Thus, the majority of respondents $(57 \%)$ indicate that delays are found in all types of projects regardless of whether the project is large or smaller. On the other hand, $53 \%$ of respondents say that the delays are not related to the length of the contractual period. In contrast, $17 \%$ of respondents indicate that delays are more frequent in medium-term projects, so an equal share of respondents (15\%) find that delays are more frequent in short-term and long-term project.

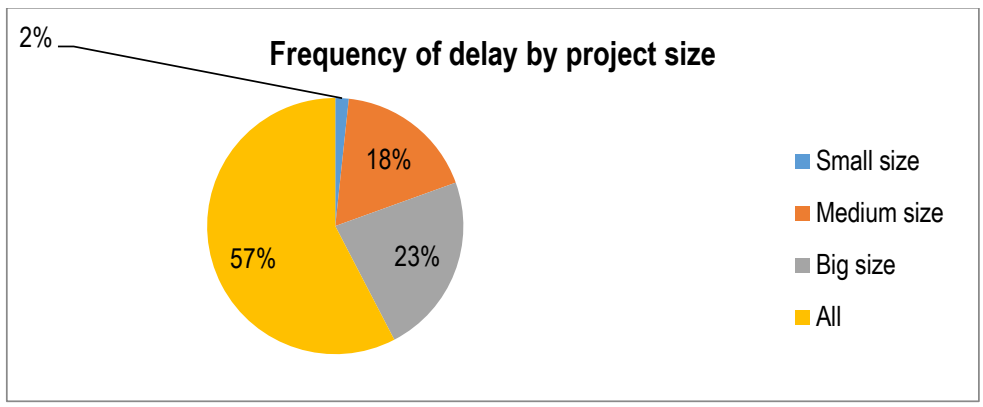

Figure 1 : Frequency of delay by project size

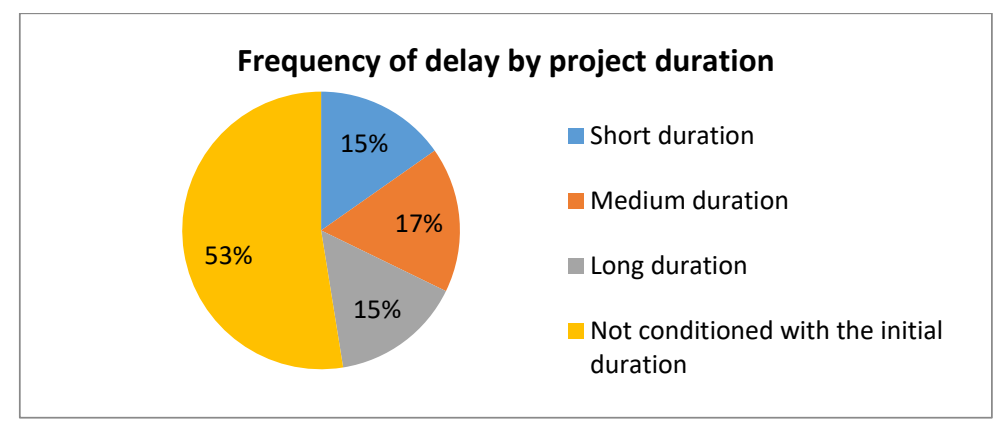

Figure 2 : Frequency of delay by project duration

\section{Assessment of delay factors}

For each delay factor, the indices of frequencies, gravities and importances were calculated. The results show that the five most common factors (see Table 1) are:

Table 1: The 5 most common factors behind delay

\begin{tabular}{|l|l|l|l|l|l|l|l|}
\hline Rank & Delay factors & \multicolumn{3}{|l|}{ Frequency of response } & FI \\
\cline { 3 - 8 } & & 1 & 2 & 3 & 4 & 5 & \\
\hline 1 & Insufficient prior studies & 6 & 16 & 27 & 35 & 34 & 3,64 \\
\hline 2 & Administrative difficulties(slow folders preparation procedure) & 2 & 17 & 34 & 44 & 21 & 3,55 \\
\hline 3 & Lack of coordination between the various stakeholders & 2 & 25 & 36 & 31 & 24 & 3,42 \\
\hline 4 & Additional works & 2 & 20 & 41 & 36 & 19 & 3,42 \\
\hline 5 & Poor quantitative estimate & 7 & 23 & 25 & 41 & 22 & 3,41 \\
& & & & & & & \\
\hline
\end{tabular}

* 1: Never, 2: rarely, 3: sometimes, 4: frequently, 5: always 
Thus, the five most serious factors (see Table 2) are:

Table 2: The 5 most serious factors behind delay

\begin{tabular}{|c|c|c|c|c|c|c|c|}
\hline \multirow[t]{2}{*}{ Rank } & \multirow[t]{2}{*}{ Delay factors } & \multicolumn{5}{|c|}{ Frequency of response } & \multirow[t]{2}{*}{ SI } \\
\hline & & 1 & 2 & 3 & 4 & 5 & \\
\hline 1 & Project mismanagement & 6 & 26 & 41 & 33 & 12 & 3,16 \\
\hline 2 & Mismanagement of human resources & 9 & 23 & 39 & 37 & 10 & 3,14 \\
\hline 3 & The lack of a planned schedule with spot phasing & 11 & 40 & 34 & 22 & 11 & 3,10 \\
\hline 4 & Lack of expertise in project management (planning, risk management) & 7 & 34 & 33 & 29 & 15 & 3,09 \\
\hline 5 & Poor supervision & 11 & 22 & 46 & 26 & 13 & 3,07 \\
\hline
\end{tabular}

* 1: Low, 2: Medium, 3: serious, 4: Very serious, 5: Extremely serious

The product of frequency and gravity is used to assess the importance of each factor, and the results show that the five most important factors are as follows (see Table 3):

- Insufficient prior studies is the most important but also the most frequent factor with an importance index of 11,7 and a frequency index of 3,64 . Preliminary studies are critical for the project success because, at the level of this latter, the owner must examine the feasibility and the expediency of the operation, analyze the needs deeply to come to a precise definition objectives and a clear formulation of the request.

- The lack of a planned schedule with spot phasing is ranked the second with IMPI=10,84; "Planning is the activity of determining and scheduling the tasks of the project, estimating their costs and determining the profiles necessary to achieve them"1. In the majority of projects planning is done in an arbitrary manner without taking into consideration the availability of resources and without a precise definition of the tasks ; this is due to the absence of specialists and planners in companies, and also due to the software used in planning.

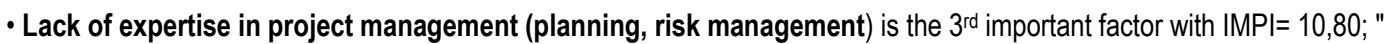
Project management is the application of knowledge, skills, tools, and techniques to project activities to meet the project requirements"2. The absence of managers and the lack of expertise in project management will lead to the failure in achievement of project objectives.

- Organizational and decisional causes, the fourth factor with IMPI $=10,59$; the organization of communication, the definition of roles and responsibilities are necessary to create lucid working conditions, improve performance and facilitate decision-making. Thus, decision-making must be done according to a structured process based on consultation, analysis and evaluation of alternatives to choose the best scenario that respects the planned cost, the expected time and the quality envisaged.

- Mismanagement of human resources is the 5th important factor with IMPI= 10,45; human resource management includes the process of organizing, directing and planning the resources required for proper execution of project, poor human resource management will lead to unavailability of resources, low productivity, lack of performance, and the delay in execution.

Table 3: The 5 most important factors behind delay

\begin{tabular}{|l|l|l|l|l|}
\hline Rank & Delay factors & FI & SI & IMPI \\
\hline 1 & Insufficient prior studies & 3,64 & 2,94 & 11,17 \\
\hline 2 & The lack of a planned schedule with spot phasing & 3,35 & 3,10 & 10,84 \\
\hline 3 & Lack of expertise in project management (planning, risk management) & 3,36 & 3,09 & 10,80 \\
\hline
\end{tabular}

${ }^{1}$ http://www.gestiondeprojet.net/articles/planification_projet.html

${ }^{2}$ A guide to the Project Management body of knowledge PMBOK® guide 5th Edition", P.5, Ed.2013PMI, 14 Campus Boulevard, Newtown Square, Pennsylvania 19073-3299 USA) 


\begin{tabular}{|l|l|l|l|l|}
\cline { 3 - 4 } 4 & Organizational and decisional causes & 3,36 & 3,02 & 10,59 \\
\hline 5 & Mismanagement of human resources & 3,24 & 1,14 & 10,45 \\
\hline
\end{tabular}

From these results, it is clear that the main causes of delays in Algeria are related to planning, organization, management. Therefore the recourse to project management is essential, firstly to predict, to anticipate, to act and to control ; Secondly to correct and to make the necessary decisions.

\section{Conclusion}

The success of projects depends on their accomplishment in the expected time, with the least cost and the best quality. In Algeria, despite the efforts made by the State in the field of construction; delays continue to be recorded.

The results of this study show that delays are not conditioned by contract duration or project size, and that $62 \%$ of projects have experienced timeotus. Furthermore, the factors causing delays in Algerian construction projects, were evaluated according to their frequencies, gravities and importance and the investigation reveals that the tops five important factors are: Insufficient prior studies ; the lack of a planned schedule with spot phasing; lack of expertise in project management (planning, risk management) ; organizational and decisional causes ; mismanagement of human resources.

The use of project and time management are essential to complete the project in a timely manner and to reach the stage of project success. Since, it optimizes the planning of activities and resources, ensures good communication, and manages all types of changes and difficulties through prevention, anticipation, organization, control, and taking the necessary corrective decisions.

\section{Recommendation}

The top 5 factors behind delay in Algeria are due to the lack of expertise and knowledge in project management. In order to solve this problem, we have proposed some managerial suggestions using the guide PMBOOK.

Table 4: Recommendation for management of the top 5 factors of delay

\begin{tabular}{|c|c|c|c|}
\hline Delay factors & Process groups & knowledge Areas & Solution \\
\hline \multirow{2}{*}{$\begin{array}{l}\text { Insufficient prior } \\
\text { studies }\end{array}$} & \multirow{2}{*}{$\begin{array}{l}\text { Planning } \\
\text { Monitoring and } \\
\text { controlling }\end{array}$} & Project integration management & Develop project management plan \\
\hline & & Project scope management & $\begin{array}{l}\text { Collect requirements } \\
\text { Define scope } \\
\text { Control scope }\end{array}$ \\
\hline $\begin{array}{l}\text { The lack of a } \\
\text { provisional schedule } \\
\text { with phasage of tasks }\end{array}$ & Planning & Project time management & $\begin{array}{l}\text { Plan schedule management } \\
\text { Define activities } \\
\text { Sequence activities } \\
\text { Estimate activity resources } \\
\text { Estimate activity durations } \\
\text { Develop schedule }\end{array}$ \\
\hline \multirow{3}{*}{$\begin{array}{l}\text { Lack of expertise in } \\
\text { project management } \\
\text { (planning, risk } \\
\text { management) }\end{array}$} & \multirow{3}{*}{$\begin{array}{l}\text { Monitoring and } \\
\text { controlling } \\
\text { Planning }\end{array}$} & Project integration management & $\begin{array}{l}\text { Develop project management plan } \\
\text { Direct and manage project work }\end{array}$ \\
\hline & & $\begin{array}{l}\text { Project humain ressources } \\
\text { management }\end{array}$ & Develop project team \\
\hline & & Project stakeholder management & $\begin{array}{l}\text { Project stakeholder management } \\
\text { Manage stakeholder engagement }\end{array}$ \\
\hline \multirow{4}{*}{$\begin{array}{l}\text { Organizational and } \\
\text { decisional causes }\end{array}$} & \multirow{4}{*}{$\begin{array}{l}\text { Planning } \\
\text { Executing }\end{array}$} & Project integration management & Direct and manage project work \\
\hline & & Project scope management & Create WBS( work breakdown structure) \\
\hline & & $\begin{array}{l}\text { Project humain ressources } \\
\text { management }\end{array}$ & Plan human resource management \\
\hline & & Project stakeholder management & Plan stakeholder management \\
\hline $\begin{array}{l}\text { Mismanagement of } \\
\text { human resources }\end{array}$ & $\begin{array}{l}\text { Monitoring and } \\
\text { controlling } \\
\text { Planning }\end{array}$ & $\begin{array}{l}\text { Project humain ressources } \\
\text { management }\end{array}$ & $\begin{array}{l}\text { Plan humain ressource management } \\
\text { Manage project team }\end{array}$ \\
\hline
\end{tabular}




\section{Bibliography / References}

[1] Assaf, S. and Al-Heji, S. (2005) "Causes of delay in large construction projects". International Journal of Project Management, Volume 24, Issue 4, pp 349-357.

[2] Long Le-Hoai, Young Dai Lee, et Jun Yong Lee. (2008) "Delay and Cost Overruns in Vietnam Large Construction Projects: A Comparison with Other Selected Countries". KSCE Journal of Civil Engineering, Volume 12, Issue 6, pp 367-377.

[3] Mohan,M. Kumaraswamy et Daniel W. M. Chan(2010)"Contributors to construction delays". Construction Management and Economics, Volume 16, Issue 1, pp17-29.

[4] M.Gündüz, Y.Nielsen et M.Özdemir. (2013) "Quantification of Delay Factors Using the Relative Importance Index Method for Construction Projects in Turkey". Journal of Management in Engineering, Volume 29, Issue 2, p 133-139.

[5] Bayana et J.Song (2016) "Empirical Study of Factors Influencing Schedule Delays of Public Construction Projects in Burkina Faso". Journal of Management in Engineering, Volume 32, Issue 5, p 05016014.

[6] A.A. Aibinu et G.O. Jagboro. (2002) "The effects of construction delays on project delivery in Nigerian construction industry". International Journal of Project Management, Volume 20, Issue 8, pp 593-599.

[7] Yakubu Adisa Olawale, et Ming Sun. (2010) "Cost and time control of construction projects : linhibiting factors and mitigating measures in practice".Construction Management and Economics, Volume 28, Issue 5, pp 509526.

[8] A.H. Alavifar, S.Q. Resalat, S. Motamedi (2014), "Identification, Evaluation and Classification of Time Delay Risks of Construction Project in Iran".

The 2014 International Conference on Industrial Engineering and Operations Management. Bali, Indonesia, January $7-9,2014$.

[9] http://www.gestiondeprojet.net/articles/planification_projet.html.

[10] " A guide to the Project Management body of knowledge PMBOK® guide 5th Edition", Ed.2013PMI, 14 Campus Boulevard, Newtown Square, Pennsylvania 19073-3299 USA). 